\title{
TEACHING SPEAKING BY USING COMMUNICATION GAMES FOR JUNIOR HIGH SCHOOL STUDENTS
}

\author{
Samsul Arifin ${ }^{1}$, Noviana Tri Purwanti ${ }^{2}$ \\ Department of English Teaching, KIP PGRI Madiun, Indonesia \\ Samsul0442@gmail.com
}

\begin{abstract}
Speaking is the most important skill to learn. Communication Games is one strategy that can be used to teach speaking. Communication Games are activities in the classroom that aim to practice oral communication. The purpose of this study was to determine the use of Communication Games in speaking teaching and the advantages and disadvantages of Communication Games in teaching speaking at the 8th grade at Nguntoronadi 1 Public Middle School in the 2013/2014 academic year. The method in this study is descriptive qualitative. The results of this study: (1) the teaching procedure of speaking with Communication Games was carried out through 3 activities. Opening, the teacher greets students, checks attendance, performs apperception. Core activities, the teacher divides students into groups, the teacher gives themes, students discuss themes, the second group guesses the first group messenger, each group makes paragraphs based on the topics obtained, the teacher helps the students difficulties, each group presents the results of the discussion. Concluding, the teacher reviews and concludes the material. This procedure is based on RPP and theories from Herrell and Jordan (2008: 95) in chapter II. (2) Advantages: Communication Games can increase students' interest in speaking, can improve student achievement in speaking, can help students actively communicate directly. The disadvantage: there are some students who are lackluster and some students are embarrassed when speaking directly.
\end{abstract}

Keywords: speaking teaching, Communication Games.

\section{INTRODUCTION}

Communication is the base of social interaction. In communication process, the people need language as their way. It is supported by Brown (2000: 5). He states that language is system of arbitrary conventionalized vocal, written, or gestural symbols that enable members of a given community to communicate intelligibly with one another. It means that language has important role for human being to communicate in form of written, oral and gesture and to interact in social community.

Based on the importance of language for human being, it appears a question, namely, what kinds of language that people should use to communicate with other people from different countries in some occasions. To answer this question, most of the people say that English is suitably. English language has acknowledged as one of widely-used language for the people in order to be able to communicate with others from different countries. As an international language, it is also considered as an importance language to be learned. Nowdays, ESL/EFL curriculum design has stressed on the importance of teaching communicative strategies and functional use of language. The fluency in speaking become 
English Teaching Journal, Vol. 4 No. 1, Juni 2016

ISSN: 2338-2678

the goal of teaching and learning language. Among of 4 language skills, speaking is the most important skill to be learnt. So, the teacher is challenged to be as creative as possible to provide opportunities for the students to expose and to reinforce the students`speaking skill. To encourage the students in practice English, some English teachers usually use games, role play, drama, and other activities which make the students pleasant in learning without bored. Unfortunately, such those activities rarely conducted at eight grade of SMPN 1 Nguntoronadi. The English teacher teaches English by using the traditional and monotonous strategy in which she just reads a dialogue loudly. After that, she asks the students to write the meaning of the dialogue and repeat the dialogue overall. Based on the problems above, the researcher is interested to apply the Communication Games as a strategy in teaching speaking for eighth grade students. According to Gibbon (in Herrell and Jordan,2008: 94) "Communication Games are activities set up in the classroom to create opportunities and purposes for verbal communication practice." It can be concluded that Communication Game is one of strategies that can be used to make the students active in verbal communication. By using the strategy of Communication Games, the teacher can build the students self-confidence to speak English. So, based on the explanation above, the researcher is interested to conduct the research entitled "Teaching Speaking by Using Communication Games as Strategy to the Eighth Grade Students of SMPN 1 Nguntoronadi in Schooling Year 2013/2014."

Related to the background of the research above, the researcher determines the statements of the problem such as: how is the use of Communication Games as strategy in teaching speaking to the eighth grade students of SMPN 1 Nguntoronadi in schooling year 2013/2014 and what are the advantages and disadvantages of teaching speaking by using Communication Games as strategy to the eighth grade students of SMPN 1 Nguntoronadi in schooling year 2013/2014.

After knowing the statement of the problem above, the researcher would like to presents the purposes of the research such as: to know the use of Communication Games as strategy in teaching speaking to the eighth grade students of SMPN 1 Nguntoronadi in schooling year 2013/2014 and to know the advantages and disadvantages of teaching speaking by using Communication Games as strategy to the eighth grade students of SMPN 1 Nguntoronadi in schooling year 2013/2014. 


\section{METHOD}

This research, the researcher uses descriptive qualitative. According to Suharsimi Arikunto (1998: 245) "penelitian deskriptif merupakan penelitian non hipotesis sehingga dalam langkah penelitiannya tidak perlu merumuskan hipotesis." It means that descriptive research is non hypothetical research. So, the process of research does not need a hypothesis. This research is conducted in SMPN 1 Nguntoronadi in the schooling year 2013/2014. The researcher chooses this school because of some reasons. They are: SMPN 1 Nguntoronadi has complete facility for supporting this research, SMPN 1 Nguntoronadi has various intelligent students and knowledge, the teachers and students of SMPN 1 Nguntoronadi have good personality, the students of SMPN 1 Nguntoronadi have various educational background and various English ability. The researcher applied this research on February to June 2014. The population of this research is all of the students in eighth grade of SMPN 1 Nguntoronadi that consist of 208 students. While the sample of this reseacrh is 8E students of SMPN 1 Nguntoronadi that consist of 25 students. In this research, the researcher uses purposive sampling technique because based on pre observation, the VIII E of SMPN 1 Nguntoronadi is choosen as the sample because the students of the VIII E have different ability in learning, and also not all the students are active in teaching learning process. The techniques of collecting data used in this research are observation, interview and documentation. Then the steps of data analysis are reduction data, displaying data and drawing conclusion.

\section{FINDINGS AND DISCUSSION}

After having a research, the researcher finds the data which are gotten through observation, interview and documentation. The research findings can be described as follows:

1. The Using of Communication Games as Strategy in Teaching Speaking to the Eight Grade Students of SMPN 1 Nguntoronadi in Schooling Year 2013/ 2014.

Based on the observation, the procedures of teaching speaking by using Communication Games as strategy to the eighth grade students of SMPN 1 Nguntoronadi in schooling year 2013/2014 consists of three steps, they are pre-activities, whilstactivities, and post-activities.

In pre-activities, the teacher begins the teaching and learning process by introduction and greeting to start the lesson. After that, the teacher checks the students' attendance list. Then, the teacher does the aperseption by relating the theme with the previous material. It is aim to make the students interested the lesson before giving the material to the students. 
English Teaching Journal, Vol. 4 No. 1, Juni 2016

ISSN: 2338-2678

Whilst activity consists of three stages, they are: exploration, elaboration, and confirmation. In exploration activities, the teacher gives stimulation to the students by giving the some questions related to the topic of the lesson. After that, the teacher asks the students to describe her/his friend that is choosed by the teacher. The students describe it based on their knowlegde. Then, the teacher explains the students about the topic that will be learnt. Next, the teacher explains the learning purposes. In Elaboration activities, the teacher explains an example about descriptive text. Next, teacher divides class into some groups. The students join with their group. Then, teacher asks the students to choose one of their group's member to be the representative of group. The students choose their representative. After that, teacher gives the theme that will be discussed. Next, teacher gives a few minutes to each group to choose a topic based on the theme that must be guessed by other group. The students discuss with their group. After that, teacher asks the representative of first group to come in front of class to act as someone else. Then, it is guessed by second group. Then, the teacher gives three minutes for the second group for guessing. The second group must look for the infomation about the representative of first group through give questioning and eliminating irrelevant items. Next, teacher gives point if the second group can guess correctly. If they could not guess correctly, the representative of first group can choose other group until the answer is correct. Then, teacher did this activities until all of groups got the topic of the material. Next, teacher gives time for all of groups to discuss and present a simple paragraph about the topic that is gotten. The students discuss together with their group. The teacher guides the students' activities and helps the students' difficulties. Then, teacher asks the students to delivered their result of discussion group by group orally. In Confirmation activities, teacher gives a score related the students' job. After that, teacher gives comments such as Good Job, Well Done, etc to build the students' motivation.

In post activities, the teacher asks the students' difficulties during the learning process. After that, the teacher concludes and reviews the material that has been learnt. Then, the teacher gives a homework related with the material. Last, teacher closes the lesson before leaving the class.

Based on the result of observation, the procedures in teacher's RPP are relevant with Herrell and Jordan's theory in chapter II which includes 7 steps. In this research, the teacher prepares well about the material that will be taught. It can be seen from the result of photograph in documentation. Besides, the material is prepared well, the teacher also 
explains the material clearly. It is also can be seen from the learning scenario in documentation. It is supported by the teacher's dialogue in learning scenario. The teacher says, "class, please pay attention to me. Here the example of descriptive text. The title is Tukul Arwana. Okay, let's analyze this paragraph one by one". It means that the teacher explains the example of a simple paragraph about describing person.

Then, based on the result of observation, the teacher teaches step by step in order that the students understand well about the material. So, the students are interested to the lesson. It is also reinforced from the result of student's interview. Student VE said that "dengan cara yang tadi, saya jadi lebih tertarik untuk berbicara dalam bahasa Inggris." It means that by using Communication Games, it makes the students interested in following the lesson.

After that, based on the result of observation, when the teacher divides class in some groups, it can be seen that the students join with their group directly. They join their group without being confused because the teacher asks the student who says A join with student who also says A. So, the class is crowded because of the students' enthusiasm. It is also supported by the result of student's interview. Student AA say that "karena kita sangat bersemangat, jadi kelas ramai." It means that the students" enthusiasm make the class crowded.

Next, based on the result of observation, the students become active and brave to give opinion when the teacher asks the second group to guess the representative of first group. The teacher gives point if they can guess correctly. If they can not guess correctly, the representative student asks the other group to guess until the answer is correct. It is also appropriate with the result of English teacher's interview. The English teacher says that "anak menjadi lebih berani untuk mengungkapkan ide-ide atau pendapat dalam bahasa Inggris." It means that the students are brave to deliver their opinions using English language.

Then, based on the result of observation, some of students in the group are passive when the teacher asks their group to deliver their result of discussion orally. They do not add their opinions to the students who deliver the result of their group. It is also supported by the result of student's interview. Student MT says that "teman-teman yang pendiam jadi pasif saja." It means that there are some students who are passive in the discussion section. 
English Teaching Journal, Vol. 4 No. 1, Juni 2016

ISSN: 2338-2678

Based on the analysis above, it can be concluded that the teaching speaking by using Communication Games process run well because the teacher teaches based on the 7 steps in Herrell and Jordan's theory in chapter II that are arranged in RPP.

2. The Advantages and Disadvantages of Teaching Speaking by Using Communication Games as Strategy to the Eight Grade Students of SMPN 1 Nguntoronadi in Schooling Year 2013/ 2014.

Based on the observation, interview and documentation, there are some advantages and disadvantages of teaching speaking by using Communication Games as strategy to the eighth grade students of SMPN 1 Nguntoronadi in schooling year 2013/2014. The advantages of teaching speaking by using Communication Games are: first, by using Communication Games, it can increase the students' interest in learning speaking. Based on the English teacher's interview, she says "ya, karena siswa menjadi lebih aktif dan kreatif. Dengan begitu mereka lebih tertarik untuk belajar speaking." It means that by using Communication Games, the students become more active and creative and they are more interested in learning speaking. Second, the students can increase their achievement in speaking. Based on the documentation in appendix 7, SKM of SMPN 1 Nguntoronadi is 76. From result of the research, 5 students get score 92, 5 students get score 88, 10 students get score 84 and 5 students get score 80 . So, it can be concluded that the achievement of students are good because the students' scores are more than SKM. Third, the students become active in verbal communication. Based on the observation in appendix 4 point 23, "grup yang bertugas menebak, mengajukan pertanyaan dalam bentuk 'yes' or 'no' questions untuk mendapatkan informasi tentang siswa yang ditebak." It means that, in using of Communication Games, there is interactions among the students by asking and giving an information. Thus, they are involved in verbal communication.

However, there are some disadvantages of teaching speaking by using Communication Games to the eighth grade students of SMPN 1 Nguntoronadi in schooling year 2013/2014. The disadvantages are: first, during the learning process, there are some of students who are not enthusiastic. Based on the observation in appendix 4 point 34, "tidak semua siswa dalam grup aktif dalam mengikuti diskusi dengan grup lain." It means that there are some students who are passive in the discussion section. Second, some of students are shy to speak orally. Based on the student's interview, the 
student AA says “ketika berbicara langsung kadang merasa canggung takut salah." It means that the student felt awkward or shy whenever he has to speak orally.

\section{Conclusion}

The procedures of teaching speaking by using Communication Games as strategy to the eighth grade students of SMPN 1 Nguntoronadi in schooling year 2013/2014 consists of preparation and teaching and learning process. In preparation activities, the teacher prepares the material of descriptive text and RPP that is used in teaching and learning process. The teaching and learning activities include pre-activities, whilst-activities, and post-activities. Pre-activities include greeting, checking attendance, and giving apperception by relating theme with previous material. Whilst-activities includes teacher explain the material about descriptive text. Then, the teacher divides the students into a small group. Each group consists of five students. The teacher makes sure that there is a leader in each group that will be the representative of the groups. After that, the teacher gives the theme about "describing person". Next, the teacher gives time for students to discuss the theme. Then, the teacher asks the representative of first group to come in front of the class and then he or she asks the others to get information through questioning and eliminating of irrelevant items. After that, the group then decides the solution based upon their inquiry. Next, the teacher moves around the class to help the students' difficulties during the discussion. The last, the teacher asks each group to deliver their result of discussion. The last, post-activities include review and conclude the material also giving the students' homework. The advantages of teaching speaking by using Communication Games as strategy to the eighth grade students of SMPN 1 Nguntoronadi in schooling year 2013/2014 are: (a) Communication Games can increase the students' interest in learning speaking. (b) Communication Games can increase the students' speaking achievement. (c) Communication Games can help the students to be active in verbal Communication. Meanwhile, the disadvantages of teaching speaking by using Communication Games as strategy to the eighth grade students of SMPN 1 Nguntoronadi in schooling year 2013/2014 are: (a) there are some of students who are not enthusiastic. (b) The condition of classroom is crowded. 
English Teaching Journal, Vol. 4 No. 1, Juni 2016

ISSN: 2338-2678

\section{REFERENCES}

B. Uno, Hamzah. 2007. Model Pembelajaran. Jakarta: Bumi Aksara.

Bahrani, Taher and Soltani Ramatollah. 2012. How to Teach Speaking Skill?. Journal of Education and Practice (online), Vol.3, No.2, (http://www.iiste.org/Journals/index.php/JEP/article/view/1147/1068 accessed on March $18^{\text {th }}, 2014$ at 4.45 p.m).

Berg. Bruce.L. 2001. Qualitative Research Methods for the Social Sciences. Needham Heights: A Pearson Education Company.

Brown, H. Douglas. 2000. Principles of Language Learning and Teaching Fourth Edition. New York: Longman

Cohen, Andrew D. 1999. Strategies in Learning and Using a Second language. New York: Longman.

Dedi Efrizal. 2012. Improving Students' Speaking through Communicative Language Teaching Method at Mts Ja-alhaq, Sentot Ali Basa Islamic Boarding School of Bengkulu, Indonesia. International Journal of Humanities and Social Science (online), Vol.

2 ,

No.20, (http://www.ijhssnet.com/journals/Vol_2_No_20_Special_Issue_October_2012/12.pd f accessed on March 12 $2^{\text {th }}, 2014$ at 10.57 a.m).

Direktorat Pendidikan Lanjutan Pertama. 2004. Bahasa Inggris. Jakarta: Departemen Pendidikan Nasional.

Edge, Julian. 2001. Essentials of English language Teaching. New York: Longman

Gulo. W. 2004. Metodologi Penelitian. Jakarta: Gramedia Widiasarana Indonesia.

Harmer, Jeremy. 2007. The practice of English language Teaching $4^{\text {th }}$ Edition. New York: Longman

Hedge, Tricia. 2010. Teaching and Learning in the Language Classroom. United Kingdom: Oxford University.

Herrel, Enne L and Jordan, Michael. 2008. 50 Strategies for Teaching English Language Learners. United States of Amerika: Pearson Education.

Horwitz, Elaine Kolker. 2008. Becoming a language Teacher. United States of America: Pearson Education.

Kayi, Hayriye. 2006. Teaching Speaking: Activities to Promote Speaking in a Second Language. The Internet TESL Journal (Online), Vol. XII, No. 11, 
(http://iteslj.org/Techniques/Kayi-TeachingSpeaking.html accessed on March $12^{\text {th }}$ 2014 at 10.31 a.m).

Kothari.C.R. 2004. Research Methodology. New Dehli: New Age International.

Littlejohn, Stephen W. And Foss, Karen A. 2008. Theories of Human Communication. USA: Thomson Higher Education.

Margono, S. 2004. Metodologi Penelitian Pendidikan. Jakarta: Rineka Cipta.

Miura, Shintaro. 2012. Strategic Communication Games: Theory and Applications. Electronic Theses and Dissertations isn`t published. St Louis: Department of Economics Washington University (http://openscholarship.wustl.edu/cgi/viewcontent.cgi?article=1618\&context=etd accessed on February $28^{\text {th }}, 2014$ at 8.14 p.m).

Narayana, Satya and Krishna.G. Curriculum Development and Management. New Dehli: Discovery Publishing House.

Noor Malihah. 2010. The Effectiveness of Speaking Instruction through Task-Based Language Teaching. Journal Register (online), vol.3, No.1, (http://journalregister.stainsalatiga.ac.id/wp-content/uploads/2013/01/85-101-JournalRegister-linguistics-language-teaching-litterature.pdf accessed on March 12 ${ }^{\text {th }}, 2014$ at 11.35 a.m)

Nunan, David. 2000. Language Teaching Methodology. Malaysia: Pearson Education. Companies.

Pupuh Fathurrohman and Sutikno, M. Sobry. 2007. Strategy Belajar Mengajar. Bandung: Refika Aditama.

Richards, Jack C. and Renandya, Willy A. 2002. Methodology in Language Teaching. USA: Cambridge University.

Sadiman, S.Arief. 2006. Media Pendidikan. Jakarta: Raja Grafindo Persada.

Sanggam Siahaan. 2008. The English paragraph. Yogyakarta: Graha Ilmu.

Sari Wahyuni. 2012. Qualitative Research Method: Theory and Practice. Jakarta: Salemba Empat.

Scott, David and Morison, Marlene. 2006. Key Ideas in Educational Research. New York: Continuum

Sugiyono. 2012. Metode Penelitian Kuantitatif Kualitatif dan R\&B. Bandung: Alfabeta.

Suharsimi Arikunto. 1998. Prosedur Penelitian. Jakarta: Rineka Cipta. 
English Teaching Journal, Vol. 4 No. 1, Juni 2016

ISSN: 2338-2678

------------------. 2002. Prosedur Penelitian. Jakarta: Rineka Cipta.

Syaiful bahri Djamarah and Aswan Zain. 2002. Strategi Belajar Mengajar. Jakarta: Rineka Cipta. 